\title{
MOŻLIWOŚCI WYKORZYSTANIA KOMUNALNYCH OSADÓW ŚCIEKOWYCH W WYBRANYCH OCZYSZCZALNIACH
}

\begin{abstract}
Osady ściekowe wytwarzane w oczyszczalniach ścieków są bogatym źródłem substancji organicznych oraz mineralnych poprawiających właściwości i strukturę gleby. Coraz większa ilość powstających osadów ściekowych skutkuje wprowadzaniem nowych rozwiązań technologicznych mających na celu ich dalsze zagospodarowanie. Opracowanie przedstawia przegląd urządzeń mających zastosowanie w dawkowaniu osadów do gleby w postaci stałej i ciekłej oraz urządzenie do poboru próbek wody infiltrującej w warunkach polowych. Artykuł zawiera również charakterystykę osadów ściekowych oraz sposoby ich zagospodarowania na przykładzie wybranych oczyszczalni ścieków w województwie podkarpackim. W opracowaniu zwrócono także uwagę na wady oraz zalety związane z wprowadzaniem osadów ściekowych do gruntu.
\end{abstract}

Słowa kluczowe: komunalne osady ściekowe, nawożenie, higienizacja, oczyszczalnia ścieków

\section{Sposoby wykorzystania osadów ściekowych}

W ostatnich dziesięcioleciach nastąpił znaczny wzrost ilości powstających osadów ściekowych, spowodowany oddaniem do eksploatacji nowych oraz modernizacją obecnie działających oczyszczalni ścieków, a także objęciem zbiorowym systemem odbioru ścieków coraz większej liczby mieszkańców, zwłaszcza terenów wiejskich oraz rozproszonych. Na podstawie zapisów Krajowego Planu Gospodarki Odpadami (KPGO) 2014 oraz prognoz demograficznych przewiduje się, że w 2018 r. w kraju zostaną wytworzone osady ściekowe w ilości 706,6 tys. Mg s.m [1]. Osady ściekowe stanowią 1-2 \% objętości oczyszczanych ścieków, dlatego ich przetwarzanie i zagospodarowanie traktowane jeszcze niedawno jako zadanie drugorzędne w stosunku do oczyszczania ścieków, szybko zaczęło nabierać znaczenia równorzędnego [2]. Stosowanie ustabilizowanych osadów ściekowych w rolnictwie jest w wielu krajach Unii Europejskiej preferowanym

\footnotetext{
${ }^{1}$ Autor do korespondencji/corresponding author: Witold Niemiec, Politechnika Rzeszowska, Al. Powstańców Warszawy 12, 35-959 Rzeszów, tel.: (17) 865 1504, e-mail: wniemiec@ @rz.edu.pl

${ }^{2}$ Marta Wójcik, Politechnika Rzeszowska
} 
oraz najbardziej rozpowszechnionym sposobem ich zagospodarowania. Podstawowym warunkiem umożliwiającym wykorzystanie osadów ściekowych jest zapewnienie bezpieczeństwa sanitarnego podczas ich stosowania [3].

Prawidłowe wykorzystanie wartości nawozowej i glebotwórczej osadów ściekowych przynosi korzyści z uwagi na obecność w osadach związków organicznych zawierających: azot, fosfor, wapń, magnez, niezbędnych do prawidłowego wzrostu roślin. Literatura [4] wyróżnia pięć głównych grup właściwości osadów ściekowych, mających wpływ na ich dalsze zagospodarowanie: fizyczne, chemiczne, sanitarne, technologiczne oraz reologiczne, przy czym najważniejsze z punktu widzenia ich późniejszego wykorzystania są cechy sanitarne. W osadach ściekowych zawarte są znaczne ilości wirusów, bakterii, pierwotniaków, a także jaja helmintów oraz inne organizmy chorobotwórcze. Ważnym kryterium ograniczającym możliwość późniejszego wykorzystania osadów ściekowych jest obecność metali ciężkich, ograniczającym ich zastosowanie do celów rolniczych. Metale ciężkie powinny być kontrolowane w przypadku składowania osadów na kwaśnych podłożach z uwagi na wymywanie toksycznych składników oraz ich przedostawanie się do gleby [6]. Kolejną cechą wpływającą na wykorzystywanie osadów ściekowych w rolnictwie jest zawartość związków biogennych. Obecność związków humusowych oraz substancji niezbędnych do wzrostu roślin powoduje, że osady ściekowe traktowane są jako wartościowy nawóz, z powodzeniem zastępujący dotychczas stosowane nawozy mineralne.

W Polsce stosuje się trzy główne metody zagospodarowania osadów ściekowych: składowanie, wykorzystywanie do celów rolniczych i przyrodniczych oraz metody termiczne. Zgodnie z Rozporządzeniem Ministra Gospodarki z dnia 8 stycznia 2013 r. w sprawie kryteriów oraz procedur dopuszczania odpadów do składowania na składowisku odpadów danego typu [5], od 1 stycznia 2016 roku będzie obowiązywać w kraju zakaz składowania osadów ściekowych na składowiskach odpadów. Z tego względu szczególne popularne staje się rolnicze wykorzystanie osadów ściekowych $\mathrm{z}$ użyciem wapna. Wapnowanie jest jedną $\mathrm{z}$ najpopularniejszych metod higienizacji osadów ściekowych. Kontakt osadów z wapnem eliminuje prawie całkowicie większość bakterii, wirusów oraz jaja Ascaris. Literatura [8] podaje, że orientacyjna dawka wapna przypadająca na jeden kilogram osadów o uwodnieniu $98 \%$ wynosi odpowiednio 7 kg CaO/kg sm. Proces odkażania osadów ściekowych za pomocą wapna jest procesem egzotermicznym, przebiegającym $\mathrm{w}$ zhomogenizowanej mieszaninie przy odczynie $\mathrm{pH}$ $=12$ oraz przy temperaturze co najmniej $5^{\circ} \mathrm{C}$ dla zainicjowania reakcji chemicznej, w czasie 75 minut. Podstawę procesu stanowi reakcja hydratacji tlenku wapna:

$$
\mathrm{CaO}+\mathrm{H}_{2} \mathrm{O} \rightarrow \mathrm{Ca}(\mathrm{OH})_{2}+\text { ciepło }
$$

$\mathrm{W}$ jednorodnej mieszaninie reakcyjnej, wapno palone reaguje $\mathrm{z}$ wodą zawartą w osadzie ściekowym. Wapno palone pochłania nawet do $32 \%$ wody w stosunku do swojej masy, co jest przyczyną znacznego odwodnienia osadu przy 
jednoczesnym wzroście temperatury. Efektem higienizacji osadów ściekowych wapnem jest gotowy bioprodukt mający zastosowanie w rolnictwie jako środek poprawiający strukturę gleby [8]. Proces higienizacji osadów ściekowych wymaga zastosowania nowych technologii i urządzeń umożliwiających produkcję wcześniej wspomnianego nawozu. Działania w zakresie wykorzystania osadów ściekowych $\mathrm{w}$ rolnictwie prowadzone są między innymi w oczyszczalniach ścieków w Sędziszowie Małopolskim oraz w Świlczy.

\section{Gospodarka osadami na oczyszczalni ścieków w Sędziszowie Małopolskim}

Oczyszczalnia ścieków w Sędziszowie Małopolskim przystosowana jest do oczyszczania ścieków o ładunku zanieczyszczeń na poziomie 18000 RLM, dopływających $\mathrm{z}$ obszaru o stosunkowo niskim stopniu uprzemysłowienia. Oczyszczalnia umożliwia mechaniczno-biologiczne oczyszczanie ścieków, wykorzystując fizyczne oraz biochemiczne procesy z udziałem osadu czynnego. W oczyszczalni oczyszcza się około $450000 \mathrm{~m}^{3}$ ścieków rocznie, co pozwala uzyskać ponad $1000 \mathrm{Mg} /$ rok uwodnionych komunalnych osadów ściekowych [9]. W ostatnich latach oczyszczalnia w Sędziszowie została zmodernizowana i wyposażona w urządzenia poprawiające efekt oczyszczania ścieków oraz higienizacji osadów ściekowych. Zastosowana technologia zapewnia wymagany stopień oczyszczania ścieków, co pozwala na odprowadzeniu ich do rzeki Budzisz. Po opuszczeniu ostatniego ogniwa technologii oczyszczania ścieków, na terenie oczyszczalni rozpoczyna się przeróbka osadów oparta na procesach: zagęszczania, stabilizacji oraz higienizacji. Osad nadmierny z oczyszczalni ścieków w Sędziszowie Małopolskim poddawany jest procesowi zagęszczania w zagęszczaczu grawitacyjnym. Podczas zagęszczania z osadu zostaje usunięty nadmiar wody, a osad ulega stabilizacji tlenowej celem unieszkodliwienia organizmów patogennych oraz nadmiernych ilości substancji organicznych. Następnie, ustabilizowany tlenowo osad poddawany jest odwadnianiu na mechanicznej prasie taśmowej z zastosowaniem polielektrolitu, który ma na celu usprawnienie prowadzonego na prasie procesu odwadniania.

W oczyszczalni ścieków w Sędziszowie Małopolskim proces aglomeracji oraz higienizacji komunalnych osadów ściekowych odbywa się z wykorzystaniem poziomej jednowałowej mieszarki, przystosowanej do ciągłej pracy. Instalacja z użyciem mieszarki zbudowana jest $\mathrm{z}$ układów mieszania, transportu oraz dozowania osadów i wapna. Osad ściekowy pobierany jest z prasy, a następnie za pomocą dwóch zwałowych podajników ślimakowych podawany jest do mieszalnika. Mieszarka wyposażona jest dodatkowo w mikrodozownik pozwalający na precyzyjne określenie wymaganej dawki wapna. W mieszarce zachodzi proces egzotermiczny, polegający na reakcji między wodą zawartą w osadzie ściekowym a tlenkiem wapnia celem osuszenia osadu i utworzenia jednorodnego aglomeratu. Zastosowana na oczyszczalni ścieków mieszarka pracuje na zasa- 
dzie mechanicznej fluidyzacji produktu. Odpowiedni kształt oraz prędkość obrotowa narzędzi mieszających wytwarzają ruch wirowy odśrodkowy w celu uzyskania złoża fluidalnego mieszaniny wapna i osadu. Zjawisko to powoduje powstanie jednorodnej mieszaniny, która ulega procesowi higienizacji oraz aglomeracji. Mieszarka jednowałowa umożliwia turbulentne mieszanie cząstek o różnej gęstości oraz wielkości w stosunkowo krótkim czasie. Powstały w wyżej wymienionym procesie produkt transportowany jest przenośnikiem taśmowym na zadaszony, wybetonowany plac na zewnątrz budynku, umożliwiający odprowadzenie powstałych odcieków do kanalizacji wewnętrznej oczyszczalni. Parametry osadu poddawanego procesowi higienizacji według starej technologii prowadzonej na oczyszczalni oraz osadu po procesie higienizacji i aglomeracji zgodnie ze zmodernizowaną technologią zestawiono w tabeli (tab. 1). Proces higienizacji pozwala rocznie wyprodukować około $2000 \mathrm{Mg}$ organicznomineralnego środka poprawiającego właściwości gleby o nazwie „FLORANEKS”. W procesie higienizacji oraz aglomeracji osadów ściekowych zużywa się średnio $400 \mathrm{~kg}$ wapna $\mathrm{w}$ stosunku do 1 tony osadów, dlatego „FLORANEKS” wpływa odkwaszająco na glebę, oraz stanowi źródło fosforu, azotu i magnezu. Produkt zalecany jest dla wszystkich rodzajów gleb. Należy zaznaczyć, że środek nie może być wykorzystywany na łąkach oraz pastwiskach z uwagi na obecność zwierząt hodowlanych.

Tabela 1. Parametry osadu ściekowego w oczyszczalni ścieków w Sędziszowie Małopolskim

Table 1. The parameters of sewage sludge in the sewage-treatment plant in Sędziszów Małopolski

\begin{tabular}{|c|c|c|c|c|}
\hline Lp. & Parametr & Jednostka & \begin{tabular}{|c|}
$\begin{array}{c}\text { Osad po higienizacji } \\
\text { według starej tech- } \\
\text { nologii }\end{array}$ \\
\end{tabular} & $\begin{array}{l}\text { Osad po higienizacji } \\
\text { i aglomeracji według } \\
\text { nowej technologii }\end{array}$ \\
\hline 1. & Odczyn & $\mathrm{pH}$ & 13,00 & 12,50 \\
\hline 2. & Sucha masa & $\%$ & 17,00 & 63,00 \\
\hline 3. & Substancja organiczna & $\%$ s.m. & 55,90 & wysoka \\
\hline 4. & Azot ogólny & $\%$ s.m. & 4,96 & 2,43 \\
\hline 5. & Azot amonowy & $\%$ s.m. & 0,09 & 0,03 \\
\hline 6. & Wapń & $\%$ s.m. & 12,06 & 41,90 \\
\hline 7. & Magnez & $\%$ s.m. & 0,92 & 0,49 \\
\hline 8. & Fosfor ogólny & $\%$ s.m. & 1,65 & 0,30 \\
\hline 9. & Ołów & mg/kg s.m. & $<15,00$ & 30,00 \\
\hline 10. & Chrom & $\mathrm{mg} / \mathrm{kg} \mathrm{s.m.}$ & 30,00 & 20,00 \\
\hline 11. & Miedź & $\mathrm{mg} / \mathrm{kg}$ s.m. & 135,00 & 32,00 \\
\hline 12. & Nikiel & mg/kg s.m. & 16,00 & 33,00 \\
\hline 13. & Kadm & $\mathrm{mg} / \mathrm{kg}$ s.m. & $<1,00$ & 2,70 \\
\hline 14. & Cynk & $\mathrm{mg} / \mathrm{kg}$ s.m. & 330,00 & 108,00 \\
\hline 15. & Rtęć & $\mathrm{mg} / \mathrm{kg} \mathrm{s.m.}$ & 0,24 & 0,08 \\
\hline 16. & $\begin{array}{l}\text { Bakterie chorobotwórcze } \\
\text { Salmonella }\end{array}$ & $\begin{array}{c}\text { obecność bakte- } \\
\text { rii/ } 100 \mathrm{~g}\end{array}$ & nie wyizolowano & nie wyizolowano \\
\hline 17. & Żywe jaja pasożytów & ilość/ kg s.m. & nie wykryto & nie wykryto \\
\hline
\end{tabular}

Źródto: opracowanie wtasne na postawie danych udostępnionych przez Oczyszczalnię Ścieków w Sędziszowie Matopolskim 


\section{Gospodarka osadami w oczyszczalni ścieków w Świlczy}

Oczyszczalnia w Świlczy umożliwia mechaniczno-biologiczne oczyszczanie ścieków z wykorzystaniem osadu czynnego, biologiczną defosfatacją, denitryfikacją i nitryfikacją. W latach 1992-2011 ciąg technologiczny oczyszczalni został zmodernizowany i obecnie pozwala na oczyszczenie około $400000 \mathrm{~m}^{3}$ ścieków rocznie [10]. Co roku oczyszczalnia w Świlczy wytwarza ponad 2700 $\mathrm{Mg}$ uwodnionych komunalnych osadów ściekowych (tab. 2). Poddany procesowi stabilizacji tlenowej osad charakteryzuje się następującymi parametrami (tab. $3)$.

Tabela 2. Ilość komunalnych osadów ściekowych wytwarzanych w oczyszczalni ścieków w Świlczy

Table 2. The amount of municipal sewage sludge produced in the sewage-treatment plant in Świlcza

\begin{tabular}{|c|c|c|c|c|c|}
\hline Rok & 2010 & 2011 & 2012 & 2013 & 2014 \\
\hline $\begin{array}{c}\text { Ilość powstających osadów } \\
\text { ściekowych [Mg] }\end{array}$ & 2765 & 2738 & 2745 & 2892 & 2120 \\
\hline
\end{tabular}

Źródto: opracowanie własne na postawie danych udostępnionych przez Oczyszczalnię Ścieków w Świlczy

Tabela 3. Parametry osadu ściekowego w oczyszczalni ścieków w Świlczy

Table 3. The parameters of sewage sludge in the sewage-treatment plant in Świlcza

\begin{tabular}{|l|l|c|c|}
\hline Lp. & \multicolumn{1}{|c|}{ Parametr } & Jednostka & Osad po procesie stabilizacji \\
\hline 1. & Odczyn & $\mathrm{pH}$ & $<10,00$ \\
\hline 2. & Sucha masa & $\%$ & $16,4 \pm 3,3$ \\
\hline 3. & Substancja organiczna & $\%$ s.m. & $48,5 \pm 9,8$ \\
\hline 4. & Azot ogólny & $\%$ s.m. & $3,76 \pm 0,77$ \\
\hline 5. & Azot amonowy & $\%$ s.m. & $0,12 \pm 0,04$ \\
\hline 6. & Wapń & $\%$ s.m. & $16,6 \pm 3,4$ \\
\hline 7. & Magnez & $\mathrm{mg} / \mathrm{kg}$ s.m. & $0,35 \pm 0,08$ \\
\hline 8. & Ołów & $\mathrm{mg} / \mathrm{kg}$ s.m. & $8,81 \pm 1,79$ \\
\hline 9. & Chrom & $\mathrm{mg} / \mathrm{kg} \mathrm{s.m.}$ & $7,54 \pm 1,53$ \\
\hline 10. & Miedź & $\mathrm{mg} / \mathrm{kg} \mathrm{s.m.}$ & $93,6 \pm 19,0$ \\
\hline 11. & Nikiel & $\mathrm{mg} / \mathrm{kg} \mathrm{s.m.}$ & $6,10 \pm 1,23$ \\
\hline 12. & Kadm & $\mathrm{mg} / \mathrm{kg}$ s.m. & $0,55 \pm 0,11$ \\
\hline 13. & Rtęć & obecność bakterii/ $100 \mathrm{~g}$ & $0,270 \pm 0,056$ \\
\hline 14. & Bakterie chorobotwórcze & nie wykryto \\
& Salmonella & ilość/ kg s.m. & 0 \\
\hline 15. & Żywe jaja pasożytów &
\end{tabular}

Źródto: opracowanie własne na postawie danych udostępnionych przez Oczyszczalnię Ścieków $w$ Świlczy

Oczyszczalnia ścieków w Świlczy wprowadza komunalne osady ściekowe do gruntu w postaci ciekłej. Do doglebowego dawkowania płynnego nawozu stosowane są starsze rozwiązania, np. wóz asenizacyjny wyposażony w adapter 
do wprowadzania ciekłego nawozu bezpośrednio pod powierzchnię gruntu (rys. 1). Głównymi elementami wozu asenizacyjnego są: zbiornik(1) oraz przewód rozprowadzający (2). Urządzenie działa w oparciu o narzędzie do iniekcyjnego wprowadzania cieczy do gruntu W-39050 (3), (rys. 2). Podstawowymi elementami maszyny do iniekcyjnego wprowadzania nawozów ciekłych do gruntu są: rama nośna (1), koło kopiujące (2), krój (3), bezpieczniki $(4,6)$, rolka dociskowa (5a) oraz rura doprowadzająca ciecz (7). Szczegóły konstrukcyjne rozwiązania podano w opisie zastrzeżeń W-39050 [11]. Stosowanie osadów ściekowych może doprowadzić do zanieczyszczenia lub skażenia gruntu substancjami toksycznymi, takimi jak: metale ciężkie oraz patogeny. W celu kontroli jakości wód gruntowych stosuje się lizymetry, przeznaczone do poboru próbek wody. Trudności w ich pobieraniu w warunkach polowych doprowadziły do opracowania lizymetru nowej konstrukcji W-116896 (rys. 3).

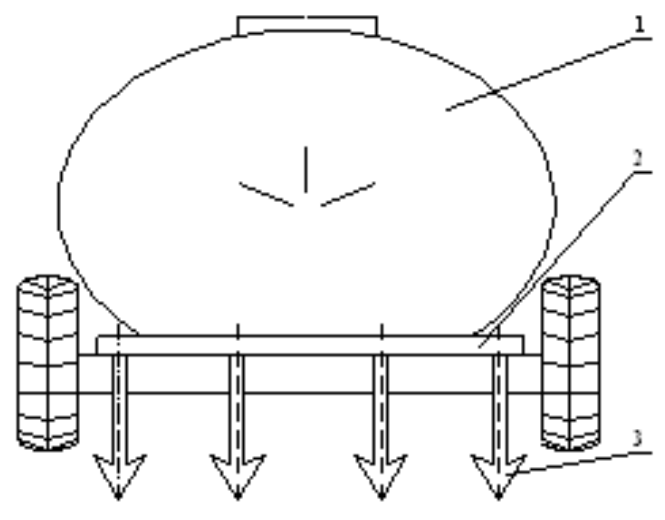

Rys. 1. Schemat ideowy konstrukcji wozu asenizacyjnego

Fig. 1. The schematic diagram of the construction of a septic tank



Rys. 2. Narzędzie do doglebowego wprowadzania cieczy do gruntu W-39050

Fig. 2. A device for injecting liquid into the ground W-39050 
Rys. 3. Schemat urządzenia do poboru infiltrującej wody w warunkach polowych

Fig. 3. Scheme of adevice to collect infiltrative water in field conditions

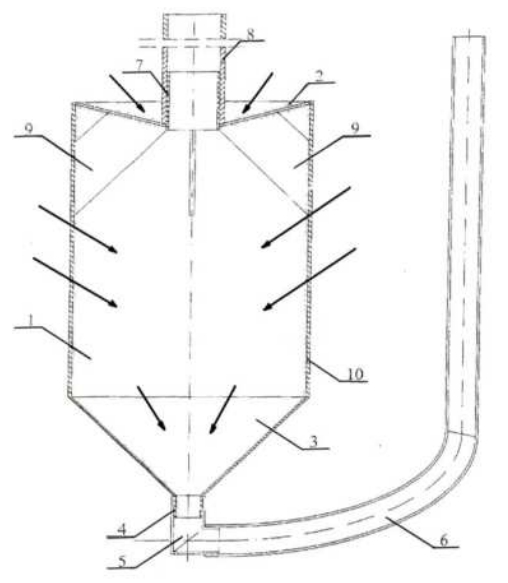

Lizymetr wykorzystywany jest do kontroli oddziaływania osadów ściekowych na gleby oraz wody na terenach plantacji. Urządzenie ma postać pojemnika zamkniętego perforowanym wiekiem z dnem w kształcie stożka zakończonego króćcem. Górne wieko oraz króciec dna zakończone są elastycznymi wężykami łącząc przestrzeń wewnątrz urządzenia z jego otoczeniem. Wodę z pojemnika pobiera się za pomocą wężyków lub przenośnej pompki próżniowej. Zaletą urządzenia jest wzmocniona konstrukcja, która pozwala na korzystanie z ciężkiego sprzętu rolniczego bez potrzeby omijania miejsca zamontowania urządzenia. Dokładniejsze dane podano w opisie zastrzeżeń W-116896 [12].

Podpowierzchniowe dawkowanie nawozów w postaci stałej posiada zalety w postaci obniżenia kosztów nawożenia oraz zwiększenie efektywności wykorzystania składników nawozowych przez rośliny. Nawóz dostarczany jest w pobliżu bryły korzeniowej rośliny z jednoczesnym przykryciem warstwą gleby celem ograniczenia straty lotnych składników nawozu. Z uwagi na duży wybór dostępnych maszyn do dawkowania stałych nawozów, zaproponowano rozwiązanie konstrukcyjne maszyny według patentu P-2104031 z innowacyjnymi przystawkami [13, 14]. Prototyp urządzenia został wykonany przez producenta maszyn rolniczych w Lublinie, a obecnie jest on testowany we wspomnianej oczyszczalni ścieków w Świlczy [7].

\section{Podsumowanie}

Ostateczne zagospodarowanie osadów ściekowych w oczyszczalniach ścieków w Polsce jest problemem kosztownym, wymagającym znalezienia docelowego rozwiązania. Gospodarka osadami powinna być dostosowana do warun- 
ków pracy oczyszczalni ścieków oraz obowiązujących standardów w zakresie postępowania $\mathrm{z}$ osadami, dlatego poszukiwane są rozwiązania mające na celu ich efektywne zagospodarowanie. Nowoczesne technologie w zakresie gospodarowania osadami ściekowymi są realizowane w nielicznych miejscach, chociaż w ostatnich latach obserwuje się tendencję do wdrażania nowych rozwiązań. Nowe urządzenia umożliwiające zagospodarowanie osadów ściekowych stosowane są w oczyszczalniach ścieków w Sędziszowie Małopolskim oraz w Świlczy.

Obecnie jedną z najbardziej popularnych metod zagospodarowania osadów ściekowych w krajach Unii Europejskiej jest ich rolnicze wykorzystanie. Zastosowanie osadów w celach nawożenia upraw energetycznych jest korzystne pod względem ekologicznym z uwagi na pozytywny wpływ na wzrost roślin. $Z$ tego względu wprowadzane są rozwiązania pozwalające na produkcję nawozów, których głównym składnikiem są osady ściekowe. Nawozy takie są alternatywą dla stosowanych nawozów mineralnych oraz z uwagi na zawartość wapna w swoim składzie mają właściwości odkwaszające oraz poprawiające strukturę gleby. Wapnowanie osadów ściekowych przynosi korzyści w postaci stabilizacji osadu bez niebezpieczeństwa późniejszego zanieczyszczenia oraz pozwala na wyeliminowanie nieprzyjemnego zapachu [15].

Należy jednak zaznaczyć, że do produkcji preparatów produkowanych z wykorzystaniem osadów ściekowych zużywane są ogromne ilości wapna, rzędu kilkaset kilogramów na tonę osadów. $\mathrm{Z}$ tego względu wymagane jest racjonalne wprowadzanie preparatów do gruntu celem uniknięcia tzw. przenawożenia gleby. Nadmierne ilości wapna są przyczyną przewapnowania gleb, powodujących szkodliwe zmiany, takie jak: przesuszenie gleb, szybszy rozkład substancji organicznej oraz przejście niektórych składników w formy trudno przyswajalne dla roślin. Niepotrzebne, a szczególnie nadmierne nawożenie przynosi skutek odwrotny od oczekiwanego - pogorszenie jakości lub nawet ograniczenie uzyskiwanych plonów.

\section{Literatura}

[1] Krajowy Plan Gospodarki Odpadami 2014 [M. P .Nr 101, poz.1183].

[2] Oleszkiewicz J.: Gospodarka osadami ściekowymi. LEM s.c., Kraków 1998.

[3] Kaźmierczuk M., Kalisz L.: Bakterie hemolizujące podstawowym wskaźnikiem skuteczności higienizacji wapnem komunalnych osadów ściekowych. Ochrona Środowiska i zasobów naturalnych, 42 (2010) 183-191.

[4] Rosik-Dulewska C.: Podstawy gospodarki odpadami, PWN, Warszawa 2008.

[5] Rozporządzenie Ministra Gospodarki z dnia 8 stycznia 2013 r. w sprawie kryteriów oraz procedur dopuszczania odpadów do składowania na składowisku odpadów danego typu [Dz.U. 2013 poz. 38].

[6] Rozporządzenie Ministra Środowiska z dnia 6 lutego 2015 r. w sprawie komunalnych osadów ściekowych [Dz.U. 2015 poz. 257]. 
[7] Niemiec W., Stachowicz F., Trzepieciński T., Ślenzak W.: Wykorzystanie osadów ściekowych do nawożenia roślin energetycznych, VI Konferencja „Metody Zagospodarowania Osadów Ściekowych”, Iława 2014, s. 105-112.

[8] Marcinkowski T.: Wpływ stabilizacji osadów wtórnych wodorotlenkiem wapnia na ich skład biologiczny, Ochrona Środowiska, 25 (2003) 49-55.

[9] Plan Gospodarki Odpadami dla gminy Sędziszów Małopolski.

[10] Gminny program ochrony środowiska dla gminy Świlcza.

[11] Niemiec W., Puchała J.: Urządzenie do wprowadzania cieczy pod powierzchnię gleb i łąk, W-39050.

[12] Niemiec W., Zdeb M.: Plantacja wierzby energetycznej nawożona osadami ściekowymi. Czasopismo Inż. Lądowej, Środowiska i Architektury, 60 (2013) 67-78.

[13] Stachowicz F., Niemiec W., Trzepieciński T., Ślenzak W.: Innowacyjne urządzenie do aplikacji doglebowej osadów ściekowych, Zeszyty Problemowe Postępów Nauk Rolniczych, nr 576 (2014) 131-139.

[14] Stachowicz F., Niemiec W., Trzepieciński T.: Method of fertilization of energy willow plantation using sewage sludge, Journal of Ecological Engineering, 14 (2013) 12-16.

[15] Ociepa-Kubicka A., Pachura P.: Wykorzystanie osadów ściekowych i kompostu w nawożeniu roślin energetycznych na przykładzie miskanta i ślazowca, Annual Set Environment Protection, 15 (2013) 2267-2278.

\section{THE POSSIBILITIES OF UTILIZATION OF MUNICIPAL SEWAGE SLUDGE IN SELECTED SEWAGE-TREATMENT PLANTS}

\section{S u m m a r y}

The sewage sludge generated in sewage-treatment plants is a rich source of organic and mineral materials improving properties of the soil structure. The increasing amount of sewage sludge produced in sewage-treatment plants effects in the introduction of new technological solutions aimed to its further management. The paper presents an overview of the devices applicable in dosage of the sludge into the soil in a solid and liquid form. Furthermore, the device to collect infiltrative water from soil in field conditions is presented. This article also contains the characteristic of sewage sludge and methods of sewage sludge management based on selected sewage-treatment plants in Subcarpathian Voivodeship. The work also presents advantages and disadvantages connected with the application of the sewage sludge into the ground.

Keywords: municipal sewage sludge, fertilization, hygienisation, sewage-treatment plant

DOI: $10.7862 / \mathrm{rm} .2015 .33$

Otrzymano/received: $14.08 .2015 \mathrm{r}$.

Zaakceptowano/accepted: 17.09.2015 r. 